\title{
Chapter 17 \\ When Moral Obligation Meets Physical Opportunity. Studying Elite Lifestyles and Power in the Saint-Tropez Area
}

\author{
Isabelle Bruno and Grégory Salle
}

Concluding their article defining promising lines of research for "exploring geographies of the super-rich", Iain Hay and Samantha Muller (2012, p. 85) "assert[ed] that there is a moral obligation on the part of those of us with the resources to do so, to undertake detailed analysis of the worlds shaped by the super-rich, and in which all of us live". The authors were probably not aware that French sociologists Monique Pinçon-Charlot and Michel Pinçon had given a similar exhortation a few years earlier. Claiming that "studying the privileged is a necessity", precisely owing to the various obstacles standing in the way of such a task, they added: "understanding society without comprehending the top of the social structure is impossible" (Pinçon and Pinçon-Charlot 2007, pp. 5-6 ${ }^{1}$ ). It was this kind of call that impelled us to take what had long been a mere laughing matter and turn it into a proper research program: a sociological (and soon also historical) study of "Saint-Tropez", more precisely the Saint-Tropez peninsula. ${ }^{2}$ Over time, we felt increasingly compelled to undertake this research, motivated by the idea that, particularly in the context of the

\footnotetext{
${ }^{1}$ See also the interview with Michel Pinçon and Monique Pinçon-Charlot in this volume.

${ }^{2}$ The Saint-Tropez peninsula — a geographical entity, not an administrative one-includes four communes: Saint-Tropez, Ramatuelle, Gassin and La Croix-Valmer. Our fieldwork focuses on the first two, particularly because the spatial setting of the area lends itself to widespread confusion over the boundary separating Saint-Tropez from Ramatuelle. More broadly, a symbolic annexation must be taken into account. Saint-Tropez, whose surface area is limited, is more than just a town; it is a brand, registered with the French National Institute of Industrial Property in 1992, an international label whose name vastly overflows its administrative boundaries and invades the surrounding territory. Consequently, "Saint-Tropez" here refers not only to a town, but to a broader area.
}

\footnotetext{
I. Bruno $(\bowtie)$

Centre d'études et de recherches administratives, politiques et sociales, Lille, France

e-mail: isabelle.bruno@univ-lille.fr

G. Salle

Centre lillois d'études et de recherches sociologiques et économiques,

Villeneuve-d'Ascq, France
} 
global financial crisis, not conducting a study on/in this area when we had the possibility of doing so would virtually amount to professional misconduct.

As already mentioned, before we took the idea seriously, it first emerged as a joke between us. There are three reasons why this was our initial attitude. First, there was the "misguided sense that this is a frivolous topic of passing interest and of little real significance" (Hay and Muller 2012, p. 83; Hay 2013, p. 1), a sense that was all the stronger given that the very name "Saint-Tropez" immediately evokes images of the futility-if not indecency-of conspicuous consumption and the flaunting of external signs of wealth. Second, at that time we were unfamiliar with the field of elite studies. We were both separately working on completely different topics, including prison issues - far removed from the glitz and glamour attached to the name "Saint-Tropez". Third, it just so happens that our actual opportunity to undertake an in-depth study of this area stemmed from a long-standing familiarity with the site, not just a subjective sense of belonging but an objective relationship. This was definitely an asset in terms of securing access to the field site, but it could later complicate the research process. We begin this chapter discussing the advantages and drawbacks of our ambivalent and unusual position, before addressing broader methodological challenges and empirical strategies.

\section{Advantages and Disadvantages of an Insider/Outsider Position}

When it comes to investigating elite lifestyles and power, there are many solid, fundamental (geographic, historical, economic, etc.) reasons to study the Saint-Tropez area, as we have argued elsewhere (Bruno and Salle 2018 ${ }^{3}$ ). The fact remains that the origin of our research was contingent. It just so happens that one of us grew up in Ramatuelle, the village adjoining Saint-Tropez on its south side. ${ }^{4}$ This is where the famous Pampelonne beach is actually located, contrary to the common (often self-interested) mistake that incorrectly situates it in Saint-Tropez. Although our study actually began in 2014, it originated in a long-standing and deep familiarity with the site on the part of one half of our duo. Not only did one of us spend her entire childhood there, but she is also the daughter of Ramatuelle's current mayor. He was first elected to this position in 2001 after starting his career as a town councilor in the mid-1980s, and has been reelected twice.

In this town, the mayor is a prominent yet approachable figure, and we can easily be publicly seen together there. Visible kinship of this kind is admittedly not without its drawbacks, especially during public disputes or controversies, as some authors have experienced in other contexts (see for example Desmond 2004). In our case, Pampelonne beach is the focus of an ongoing social and legal conflict that is

\footnotetext{
${ }^{3}$ This chapter borrows elements of that article.

${ }^{4}$ It is actually both a village and a town. According to the last official census, the population of Ramatuelle was under 2200 in 2015; however, because of the high number of tourists, the village is officially listed among towns with populations of 20,000 to 40,000 .
} 
intense and persistent. It is arguably one of the most prominent "beach battles" in the world, lasting approximately 30 years and involving various key players, including the municipal government (Bruno and Salle 2017). This context makes it difficult to approach some of the beachside managers and owners, who are battling with local authorities, and convince them that we are carrying out an independent study. Most of them are already secretive enough, but this is exacerbated by the fact that they make almost no distinction between social scientists and journalists.

Yet experience shows that the advantages of kinship far outweigh the disadvantages. As a matter of fact, the main obstacle we face is that we live and work on the other side of the country, and this forces us to conduct our research in a discontinuous way. When on the ground, the mayor's social capital has facilitated direct or participant observations in closed (private and/or expensive) locations and at society events, such as a polo match. It is also beneficial with regard to local (municipal) archives, to which we are unusually granted full, direct, open access, thanks to special arrangements. It was also easier for us to organize interviews with wealthy seasonal residents, some of whom the mayor associates with regularly, if superficially. The benefits go beyond mere access, affecting the very conditions in which interviews take place. Some authors have discussed the difficulties of interviewing elites (unequal power relations, verbal self-control, time management, etc.), and strategies for overcoming these obstacles (e.g. Morris 2009; Rice 2010; Harvey 2011). In our case, we could add that the implications of conducting interviewsarranged through an acquaintance-with highly placed actors who are on vacation far away from their workplace, are ambivalent. On the one hand it might seem easier, in the sense that the interviewees are well-disposed towards us and the interviews are quite relaxed and informal. On the other hand, and for the same reasons, interviewees can be reluctant to talk about sensitive, "serious" matters, so there is a risk that we might obtain only trivial information. More generally, having family ties on-site, and therefore having the opportunity to stay there either at regular intervals or over a long period, would seem to be a requisite for adopting a genuine ethnographic approach in this case. Indeed, the cost of living in the area in question has now become so high than even camping for only a few weeks each year would be very expensive. ${ }^{5}$ Another factor that is far from trivial is that the practical knowledge of the area that comes with site familiarity proves to be very useful when carrying out day-to-day fieldwork.

In their "investigation diary" [journal d'enquête], Monique Pinçon-Charlot and Michel Pinçon (2011 [1997], esp. p. 64-66; also Khan and Jerolmack 2013) have given a good explanation of how working in pairs can be helpful, particularly when direct or participant observation is involved. In our case, our unusual position enables us to develop a dual perspective, between familiarity and unfamiliarity, and

\footnotetext{
${ }^{5}$ Although the issue of inequality is once again on the social science agenda in France (and elsewhere), the fact is that, understandably, getting substantial grants to study the top of the class structure is not an easy task, and may appear irrelevant or even inappropriate. Therefore, family ties on site are all the more valuable. For instance, they also conditioned the comparable research conducted by Bruno Cousin and Sébastien Chauvin (2013) on/in Saint-Barthélemy (St. Barts).
} 
this in two ways. First, as already mentioned, one of us is a "local girl", familiar with the environment and the local population; yet in her youth she was only a lay witness to ostentatious wealth, herself living in social housing that was built in the 1970s so that local workers could live not far from their workplace. Second, the other of us was initially a total stranger to the place, making it easier to take a step back from the field site. We can play upon this dual insider/outsider position in the course of our study, by assuming the contrasting roles of the "native" one and the "naive" one. It proves to be heuristic, insofar as the comparison between our points of view, inherited from different socializations, helps what Pierre Bourdieu used to call the objectification of the objectifying subject (Bourdieu and Wacquant 1992, p. 213-215), that is to say the cultivation of a reflexive relationship to the field of study before, during and after the fieldwork. Since fieldwork in the strict sense means direct observation, it is worth considering both its benefits and its limitations in the present case.

\section{The Benefits and Limitations of Observation}

As ethnographers, we are inclined to give primacy to direct observation and physical experience-perhaps too much primacy when observation is a de facto end in itself rather than a means of supporting an argument, and is insufficiently related to the aim of the research. Here again, the contribution that direct observation actually makes to sociological knowledge proves to be debatable. Obviously, when it comes to documenting or capturing elite lifestyles, direct observation has supreme advantages. It makes it possible to provide first-hand descriptions of scenes that, though not necessarily visually spectacular-such as quietly spending the afternoon chatting and drinking upmarket champagne around the pool at an elegant villa-nonetheless characterize upper-class lifestyles. It is one thing to hear or read about it, but quite another to witness and even experience it. That said, observations might still not be very significant per se. In the case of the villa just mentioned, a proper interpretation of the scene requires sociological information about the owner of the place. He was born and raised in a very modest social situation, as the son of a poor Italian sharecropper. He first belonged to the working class as a factory worker before establishing himself as the owner and chef of a high-end restaurant. Therefore, the scene is noteworthy not so much from a descriptive point of view, but rather as an empirical illustration of a swift upward mobility emblematic of the socioeconomic effects that the transformation of a rural village into an elite haunt has on the locals. In short, here — as on any other field site-we should bear in mind that observation is only valuable in connection with the other methods involved in the research process, which itself depends on how the subject is problematized.

Moreover, one could argue that in our "expository society" (Harcourt 2015) and all the more in a much-discussed place like Saint-Tropez, whose reputation hinges on the celebrities that notoriously visit it-direct observation quite often serves to confirm intuitions or second-hand knowledge, instead of bringing fresh 
insights. Before even stepping onto the field site, some documents (primarily gossip magazines, society newspapers and websites, specialized publications like yachting magazines, and occasionally the mass-media) do in fact provide detailed, if frivolous, accounts of elite lifestyles. For example, a fawning description of a day spent inside and outside the superyacht of some celebrity might provide useful information about the area's hotspots, its social network, maybe its residential property, and so on. If carefully chosen and thoroughly examined, a vast collection of these written sources could be enough to get a rough but passable picture of elite lifestyles. It would also provide a good sense of one aspect that makes Saint-Tropez sociologically interesting: the heterogeneousness of the elite in terms of its spheres of activity (as well as its spheres of power and influence), from big business to show business, from the pharmaceutical industry to finance and sport. In this respect, a descriptive ethnography can certainly sketch a more vivid and accurate picture, but whether or not it adds much in terms of substantial knowledge is uncertain. After all, when Charles Wright Mills (1956) made his powerful sociological statements in The Power Elite, there were based on few direct observations; moreover, he somewhat downplayed the value of ethnographic accounts, at least in the case of local community studies. ${ }^{6}$ And if we are to demonstrate the existence of a ruling class, for example, a well-designed statistical analysis is most probably the best option (Denord et al. 2018).

In our case, observation proved priceless not on methodological principle, but for empirical reasons. Particularly in a case like that of Saint-Tropez, most public documentation only provides access to the tip of the iceberg, that is to say-to borrow from Mills' typology_-"celebrities", and secondarily "the very rich". And not even all of them, but only the most visible segment, including those who indulge in the paradoxical behavior we have oxymoronically termed "conspicuous seclusion"super-yachting being the paradigmatic illustration (Bruno and Salle 2018). As a result, the researcher is inclined to primarily examine what Saint-Tropez is already well-known for, namely for being a place of ostentation, consisting not only conspicuous consumption, but also social parading. Therefore it only gives a partial and possibly distorted view of what Mills called "local society", which in our case includes "chief executives" and "the corporate rich" (nowadays we should add "top executive managers"), who are wealthy but do not necessarily make headlines. This is where fieldwork can help complete the picture, highlighting what is less visible by definition, namely the mechanisms of social closure. This is all the more relevant in that the "retrenchment" or even "exit" of elites can be seen as characteristic of the current age of inequality (Friedman 2004), although it is consistent with a long-term trend described by historians that sees the rich increasing their ability to entrench themselves behind closed doors, keeping members of other social classes at arm's length.

\footnotetext{
${ }^{6}$ Mills (2000 [1956], p. 386-387) only offered observations and field notes in the second chapter, "Local Society". In that same footnote, however, he writes: "Most local community studies of prestige, so often the unit of sociological study, are of merely local interest." He then draws a parallel between descriptions by sociologists and by novelists - to the advantage of the latter.
} 
This entrenchment itself mirrors two aspects or tendencies that only fieldwork can fully clarify. The first is a deep, quiet process of renewal of the elite on the territory under consideration, an elite that values discretion over ostentation, reserve over publicity. Elite practices are gradually changing, with seasonal wealthy residents shunning outings to the town's public places and nightspots in favor of private parties or catered receptions in villas, even with chefs in the kitchen and servants in livery, not to mention private security at the gates. This is why it would be wrong to cling to stereotypes of Saint-Tropez as a hangout strictly reserved for flashy jetsetters, provided that we give attention to places other than nightclubs. The second is the relative social decline of what used to be established as the upper class in this area during the 1980s and 1990s. The influx of super-rich newcomers has "raised the stakes" too high, causing the established upper class (particularly, but not limited to, the French upper class) to undergo a drop in status that, when they speak of it, is tied to the lament that the area has lost its "spirit" or "authenticity". This is an expression of the fact that Saint-Tropez is - or has historically become-a distinct site of one-upmanship. In this respect, it captures not only the elite's homogeneity, but also its heterogeneity, both "horizontally" in terms of spheres of activity, but also "vertically" in terms of socioeconomic hierarchy. Given that the top percentile of wealth distribution is more internally differentiated than any other, one major benefit of this investigation site is that it makes it possible to work at a limited scale, not just on the wealthiest among the so-called "1\%", but also on the various categories that make up this fraction; not only the more or less famous "superrich", but also more anonymous people of privilege.

\section{By All (Consistent) Means Available}

We social scientists sometimes lose sight of what should be obvious: that the value of a method only depends on whether it is or is not consistent with our research interests and the questions we raise (see Lahire 2012). Is it about giving the reader a vivid sense of a social world he/she does not know about, by providing a more detailed description of scenes, practices and places of sociability that are usually depicted in a simplistic way? Or documenting the physical and symbolic mechanisms of social closure? Or defining the typical characteristics of a social lifestyle? Or taking a position with regard to the unity or diversity of the elite, or is it about the debatable existence of a global dominant class? Or showing how the power that elites exert over space is at the core of their social reproduction?

Adopting the latter perspective (Pinçon and Pinçon-Charlot 2018), one objective of our study is to challenge the standard-if not official-historical accounts of Saint-Tropez, which narrowly focus on the (supposed) leading role played by a handful of celebrities. In particular, we seek to challenge a deep-rooted narrative that says the natural beauty of the area was destined to attract "tasteful" people. This narrative tries to explain the region's longstanding popularity among elites, dating back as far as the late nineteenth century, by recounting how eminent outsiders 
spontaneously arrived in waves, attracted by the irresistible appeal of the place. To challenge this view, we highlight the generally overlooked fact that, over the course of a long-term process, the place had to be "made appropriate" for elites so they would be likely to "appropriate" it. And to show this-which entails unearthing forgotten or little-known facts (particularly concerning land-use planning) — there is no better method than digging into archives.

Given the obstacles already mentioned, our empirical strategy is, as a general rule, to use all of the means at our disposal, and cross-reference sources whenever possible. For example, in order to piece together the history of the Pampelonne beach clubs, we used a special issue of a society yearbook containing interviews, some of which were with people who are no longer accessible, and we crossreferenced them with local archives. To get sociological information on people renting superyachts, we went out on the water with members of the local marine observatory, who were themselves trying to get information as part of a project to create special mooring areas for superyachts. To get a picture of the different social groups permanently or seasonally living in Ramatuelle, we built a dataset based on one hundred marriages celebrated at the town hall. The speech given at these events by the mayor (or a deputy) provides more or less detailed facts about the social background of the newlyweds, such as where they were born and raised, their education, their occupations, and in some cases even their favorite leisure activities (which can be an indication of their class). This information (crossed-referenced with other sources when available) makes it possible to establish a typology in which three distinct profiles clearly appear, including low-income people who have nothing to do with wealthy seasonal residents socially, except as subordinates in a service relationship. All in all, even though the place we are studying might be unusual in some ways, we apply the usual techniques of the social sciences.

Pampelonne beach, which we already mentioned, deserves special attention. At the beginning of our research, it was only one observation site among others, but then it became an object of study in itself. This beach is a social scene that can reveal elite lifestyles, given that expensive beach clubs are typical of the "conspicuous seclusion" logic we mentioned earlier. But there is more. We wanted to challenge the local conventional wisdom, which says that whatever it may cost to eat in the beach restaurants, the beach is still available "for everyone", "for the common man", given that most of the beach (about three-quarters) remains free of charge. It is then presumed that as a result of this, Pampelonne beach is frequented by people who have a wide range of social statuses. And yet observation would seem to make it quite clear that the upper class is overrepresented, even on the free parts. Now how do we prove it? We had no choice but to devise a quick questionnaire and ask beachgoers to complete it on the spot, trying to get a sample that was as representative as possible. In addition to enabling us to collect data, this short survey was also a way for us to initiate informal interviews with the people we met. 


\section{Conclusion}

If, like us, one agrees with the conception of social life as both relational and conflictual, as opposed to the stratification approach in particular (Wright 2015), then it is clear that the upper class cannot be studied in isolation. If the top of the social structure is spatially secluded, for example, this in no way means that it has no effect on its surroundings. In this respect, we not only subscribe to the idea that the study of elites must be linked to class analysis (Savage 2015), but we also aim to include them in a sociology of domination that gives attention to the power that a few people exert over others. Even though elite lifestyles are an integral part of our research, they are not its focus, which more broadly concerns economic inequality and social domination. For this reason, our study gives attention to the viewpoint of locals, who are led to rub shoulders with the elite without being part of the same world. Working in/on Saint-Tropez, we cannot help thinking of a statement made by historian Alain Corbin (1994, p. 232; also see Vincent 2008), who said that "the people of the shores were scarcely visible except through a process of domestication that brought them into the service of members of the leisure class". From this perspective, a fully-fledged sociological study of the Saint-Tropez area should also go counter to common perceptions, by scrutinizing the lower echelons of the social structure. Saint-Tropez certainly offers a precious vantage point from which to study the elite. Getting the full social picture, however, calls for the consideration of a more unexpected question: what does it mean to belong to the working class, and more specifically to the "precariat", in Saint-Tropez?

\section{References}

Bourdieu, P., \& Wacquant, L. (1992). An invitation to reflexive sociology. Chicago: The University of Chicago Press.

Bruno, I., \& Salle, G. (2017). "État ne touche pas à mon matelas !" Conflits d'usage et luttes d'appropriation sur la plage de Pampelonne. Actes de la recherche en sciences sociales, 218, 26-45.

Bruno, I., \& Salle, G. (2018). "Before long there will be nothing but billionaires!” The power of elites over space on the Saint-Tropez peninsula. Socio-Economic Review, 16(2), 435-458.

Corbin, A. (1994). The lure of the sea: The discovery of the seaside in the Western world (1750-1840). Berkeley/Los Angeles: University of California Press.

Cousin, B., \& Chauvin, S. (2013). Islanders, immigrants and millionaires: The dynamics of upperclass segregation in St Barts, French West Indies. In I. Hay (Ed.), Geographies of the super-rich (pp. 186-200). Cheltenham: Elgar.

Denord, F., Lagneau-Ymonet, P., \& Thine, S. (2018). Primus inter pares? The French field of power and its power elite. Socio-Economic Review, 16(2), 277-306.

Desmond, M. (2004). Methodological challenges posed in studying an elite in the field. Area, $36(3), 262-269$.

Friedman, J. (2004). The relocation of the social and the retrenchment of the elites. Social Analysis, $48(3), 162-168$. 
Harcourt, B. E. (2015). Exposed. Desire and disobedience in the digital age. Cambridge: Harvard University Press.

Harvey, W. S. (2011). Strategies for conducting elite interviews. Qualitative Research, 11(4), 431-441.

Hay, I. (Ed.). (2013). Geographies of the super-rich (pp. 186-200). Cheltenham: Elgar.

Hay, I., \& Muller, S. (2012). 'That tiny, stratospheric apex that owns most of the world'. Exploring geographies of the super-rich. Geographical Research, 50(1), 75-88.

Khan, S., \& Jerolmack, C. (2013). Saying meritocracy and doing privilege. The Sociological Quarterly, 54, 8-18.

Lahire, B. (2012). Monde pluriel. Penser l'unité des sciences sociales. Paris: Seuil.

Mills, C. W. (1956). The power elite. Oxford: Oxford University Press.

Morris, Z. S. (2009). The truth about interviewing elites. Politics, 29(3), 209-217.

Pinçon, M., \& Pinçon-Charlot, M. (2007). Sociologie de la bourgeoisie. Paris: La Découverte.

Pinçon, M., \& Pinçon-Charlot, M. (2011 [1997]). Voyage en grande bourgeoise. Journal d'enquête. Paris: PUF.

Pinçon, M., \& Pinçon-Charlot, M. (2018). Social power and power over space: How the bourgeoisie reproduces itself in the City. International Journal of Urban and Regional Research, 42(1), $115-125$.

Rice, G. (2010). Reflections on interviewing elites. Area, 42(1), 70-75.

Savage, M. (2015). Introduction to elites: From the 'problematic of the proletariat' to a class analysis of 'wealth elites'. The Sociological Review, 63, 223-239.

Vincent, J. (2008). L'intrusion balnéaire. Les populations littorales bretonnes et vendéennes face au tourisme (1800-1945). Rennes: PUR.

Wright, E. O. (2015). Understanding class. London: Verso.

Open Access This chapter is licensed under the terms of the Creative Commons Attribution 4.0 International License (http://creativecommons.org/licenses/by/4.0/), which permits use, sharing, adaptation, distribution and reproduction in any medium or format, as long as you give appropriate credit to the original author(s) and the source, provide a link to the Creative Commons license and indicate if changes were made.

The images or other third party material in this chapter are included in the chapter's Creative Commons license, unless indicated otherwise in a credit line to the material. If material is not included in the chapter's Creative Commons license and your intended use is not permitted by statutory regulation or exceeds the permitted use, you will need to obtain permission directly from the copyright holder.

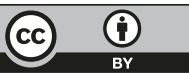

